\author{
O.S. Khokhlova ${ }^{1}$ and A.O. Nagler ${ }^{2}$ \\ ${ }^{1}$ Institute of Physicochemical and Biological Problems in Soil Science, \\ Federal Research Center "Pushchino Scientific Center for Biological Research \\ of the Russian Academy of Sciences", \\ Institutskaya 2, Pushchino, 142290, Russia \\ E-mail: olga004@rambler.ru \\ ${ }^{2}$ Deutsches Archäologisches Institut, Eurasien-Abteilung, \\ Im Dol 2-6, Haus 2, 14195, Berlin, Germany \\ E-mail:Anatoli.Nagler@dainst.de
}

\title{
The Marfa Kurgan in the Stavropol Territory: An Example of an Ancient Architectural Structure
}

This study focuses on the analysis of structural elements of the Marfa kurgan in the Stavropol Territory. We list and examine terms referring to such elements, and suggest our own. A description of the kurgan, its natural environment, excavation techniques, sampling, and analytical methods is provided. The material of which the kurgan was made is assessed, and its advantages over other materials are demonstrated. We studied mud blocks (or "bricks"), their clay coatings, and a striped adobe element from the kurgan. Results of chemical and granulometric analyses are outlined, along with those of the micromorphological analysis of soils underlying the kurgan, of the material of which the "bricks" and the coatings were made. The blocks were molded by thoroughly kneading and compacting a moistened material consisting of loess with the addition of river silt, without plant admixture. Clay coatings were much denser, as it consisted of a coherent finely dispersed clay-carbonate material. Clay mortar, similar to coatings in composition and properties, was used to connect the blocks and the stones of the crepidoma. The same mortar was used for foundations of clay "bricks" buildings. The adobe element with thinnest variously colored stripes resulted from a destruction of an earlier structure.

Keywords: Kurgan construction, Early Bronze Age, clay blocks, "bricks", soil science methods, micromorphology, Stavropol Territory.

\section{Introduction}

In the past, the steppes of Eurasia were inhabited by various tribes and peoples, who left behind kurgans, which are striking (and often the only) evidence of their distinctive and expressive culture. These kurgans are the most numerous archaeological sites on the continent, located in large or small groups, and they are an integral part of the steppe landscape. Even according to rough estimates, in each of the steppe regions there are several thousand kurgans (Nagler, 2015).
Kurgans usually look like sod hills with rounded bases, sometimes with a flattened peak, often surrounded by moats. In the Central Asian region, there are also structures built of stones and rectangular in plan view. Kurgans, having originally been temples or sanctuaries, may not contain burials (Parzinger et al., 2003).

In the archaeological literature, the prevailing opinion is that a kurgan is a mound over the graves (see (Efremova, (s.a.))). When describing a kurgan, archaeologists, even when seeing that such a barrow is formed, say, from pieces of sod, do not decline from using

Archaeology, Ethnology \& Anthropology of Eurasia 48/2 (2020) 38-48 E-mail: Eurasia@archaeology.nsc.ru (C) 2020 Siberian Branch of the Russian Academy of Sciences

(C) 2020 Institute of Archaeology and Ethnography of the Siberian Branch of the Russian Academy of Sciences

(C) 2020 O.S. Khokhlova, A.O. Nagler 
the word "mound". The term "mound" appears in works devoted to kurgans, which were constructed using clay, sod blocks, wood, and stone (see, e.g., (Rolle, Mursin, Alekseev, 1998; Mozolevsky, Polin, 2005; Chernykh, Daragan, 2014)).

As far back as 1960, the archaeologist M.P. Gryaznov pointed out that a kurgan is a collapsed ancient architectural structure (1961). However, this definition has not become common in archaeology; the terms "mound" and "fillingups" continue to be used, and the kurgans are not excavated as architectural structures. This situation has already been analyzed and discussed in the archaeological literature (Nagler, 2013b, 2015, 2017).

According to a definition proposed by A. Nagler, a kurgan is a funeral-memorial complex, which includes:

burials, hoards, sacrificial complexes;

structures built above them, sometimes complex and monumental, which are the monuments of a particular architecture; and

the territory adjacent to the structure, or the kurgan periphery, on which there are cultural remains associated with both the construction of the complex and the ritual activities; artifacts, and sometimes graves (Ibid.; Nagler, 2013a).

As a rule, when excavating kurgans in the steppe zone of Russia, archaeologists and soil scientists carry out their research in order to reconstruct paleoclimatic conditions or past anthropogenic impacts on the natural environment only on paleosols buried under objects. The materials which the kurgans proper are composed of are studied much less often (Zdanovich, Ivanov, Khabdulina, 1984; Aleksandrovsky, Khokhlova, Sedov, 2004; Bazhenov et al., 2013; Plekhanova, Demkin, Manakhov, 2005; Borisov et al., 2019). A kurgan could be built from pieces of sod- "sod blocks", cut from the soil, and laid down in a certain order. For adhesion between them, clayey ground was poured. The use of plant material was also noticed (Golyeva, Khokhlova, 2010). However, when describing the kurgans, the terms "mound" and "filling-ups" are used, which does not assume that they be considered integrated structures.

Preliminary findings from the Marfa kurgan in the Stavropol Territory indicate that clay (earthen) blocks were used to create the structure (Nagler, 2015; Khokhlova, Khokhlov, Nagler, 2017; Khokhlova, Nagler, 2018). Phytolith analysis of samples taken from the kurgan structure evidenced the absence of plant materials in blocks and other elements of the kurgan. According to international researchers, in areas with an arid climate, structures were constructed from unburnt clay or sun-dried mud "bricks"; these blocks are used in construction today (Love, 2017). And although clay blocks are archaeological artifacts, archaeologists study them relatively seldom. Sun-dried mud "bricks" were used as a building material as early as eleven thousand years ago (Friesem et al., 2014). At the beginning of the 4th millennium BC, the Sumerians built temples, palaces, dwellings, and outbuildings from them (Kramer, 2010). In ancient Egypt, exact recipes for making such blocks were known. For construction, most often they made blocks of clay mixed with chopped straw. No plant components were added to the earthen material with sufficient clay content. Unbaked mud bricks with a clay content of no more than $30 \%$, and sand no less than $50 \%$, were considered the best (Emery, 2011; Hohn, 2003; Kemp, 2000). If the clay content exceeded $50 \%$, then such blocks shrank when dried, and got covered with cracks (Rosen, 1986). Buildings erected from earthen blocks were strong and durable, more resistant to various environmental influences than structures made of stone and wood. Many archaeological monuments and architectural structures were built of clay or sun-dried mud "bricks".

In geoarchaeology, structures constructed from earthen blocks are widely studied by science-based methods, chief of which is the micromorphological approach (Goldberg, 1979; Courty, Goldberg, Macphail, 1989). Using this approach, it was found that there were most often three grades of clay used (Friesem, Watter, Onfray, 2017).

The clay served as the basis for the manufacture of sun-dried mud "bricks". To do this, it was mixed with water, and often with plant material, which acted as a bonding agent. Structures were then laid out from lumps of the clay mass, also obtained by mixing earth (mud) material with water, without preliminary molding and drying (formwork was sometimes used for this). The clay put into structure was compacted in the dry state in situ.

In the course of experimental studies conducted by international scientists using a light microscope, the relationship between the appearance of the earthen block and the technological methods of the construction of an adobe structure was traced (Cammas, 2018). There are no data on the study of earthen archaeological structures by Russian scientists using the science-based methods, in particular micromorphological (Bronnikova et al., 2016).

The purpose of this work is to study the earthwork of the Marfa kurgan in the Stavropol Territory by geoarchaeological methods, in particular micromorphological one. Notably, the space of this article does not allow us to consider the entire construction of Marfa kurgan in detail; therefore, most of our attention will be focused on the study of clay blocks, their coating, and the technology of adobe construction.

\section{Object and methods}

\section{Object}

The Marfa kurgan is located on the territory of the Kirovsky District of the Stavropol Territory, near 
Komsomolets village and the city of Novopavlovsk $\left(43^{\circ} 58^{\prime} 37.98^{\prime \prime} \mathrm{N}, 43^{\circ} 30^{\prime} 58.49^{\prime \prime} \mathrm{E}\right)$. In geomorphological terms, this is the Kabardin foothill plain, with absolute heights in the range of 200-500 $\mathrm{m}$ a.s.l. The kurgan is located on a high terrace of the Zolka River, which is a right tributary of the Kuma River. Although the territory all around the kurgan was completely ploughed, the kurgan itself was not; large tracts of arable land are separated from each other by forest belts. The kurgan, with a height of $7 \mathrm{~m}$ and a diameter of 40-60 m, began to be built by members of the Maykop culture in the Early Bronze Age (second half of the 4th millennium BC). It was completed in the Middle Bronze Age (3rd to 2nd millennium BC) and in the Early Iron Age (1st millennium BC). The Marfa kurgan was completely excavated in 2013-2015 by a joint expedition of LLC "Naslediye" (Stavropol, Russia) and the German Archaeological Institute (Berlin, Germany).

\section{Natural conditions}

The climate in the territory near Novopavlovsk is temperate continental, the average annual temperature is $11-12{ }^{\circ} \mathrm{C}$, the average temperature in July is $22.4^{\circ} \mathrm{C}$, in January $-3{ }^{\circ} \mathrm{C}$; winters are short and mild, summers are long and warm (https://ru.climate-data.org/location). According to hydrothermal conditions, the climate is characterized as arid, the average annual rainfall is 520 $570 \mathrm{~mm}$, the moisture coefficient (the ratio of the average annual rainfall to evaporation) is $0.7-0.8$.

According to the vegetation cover, the territory under consideration belongs to the subzone of plainforb-grass-steppes, with a high and dense grass stand. Currently, areas with natural vegetation adjoin arroyos inconvenient for sowing, steep slopes, and places with shallow occurrence of stony rocks. The basis of the soil cover of the flat part of the territory is ordinary black earth (migration-segregation or Calcic Chernozems), which is characterized by an increased thickness of the humus horizon. Soils are formed of carbohydrate and in some places gypsum loess-like clays and loams from the Quaternary period.

\section{The methodology of the archaeological work}

When excavating the Marfa kurgan, archaeologists were guided by the field research methodology adopted in Russian archaeology. Since it does not include excavation of the kurgan as an architectural structure, not only the vertical surfaces of the stratigraphic baulks were cleaned, but also the horizontal surfaces of the kurgan (Fig. 1, $a, b$ ), as well as its structures in deep layers (Fig. 1, c), with clearing the clay sun-dried mud "bricks" from which it was built. In accordance with the proposed definition of the kurgan, the study of the so-called kurgan periphery was suggested; therefore, horizontal scraping was carried out on the territory adjacent to the object. This made it possible to identify sites, on one of which there was a heavily damaged clay block structure (Fig. 1, $d, e$ ). The sites were paved with clay blocks similar to those used to create the kurgan. It is important to note that the objects found on the periphery, although they were in the zone of recent intensive tillage, were not completely destroyed.

The material evidence for construction consists not only of the blocks, but also of mud coating-pieces of hardened mortar, which had cementing properties. Blocks-"bricks" were coated with liquid mortar for fastening, or the masonry was fixed. The clay mass, laid out in an even and relatively thick layer $(10-20 \mathrm{~cm})$ on the blocks, formed the "foundation" for the next structures of blocks inside the kurgan. Three types of coating were identified: the "foundation" for construction, found in the northern part of the kurgan, as well as coatings on the blocks or stones of yellow (loess) and gray-brown color (Fig. 2, $b$ ).

On the southern side of the kurgan, during the vertical cleaning of baulk R3 under the masonry, an unusual fragment of the structure was discovered - a lens of earthen material with a thin-striped pattern on the surface (Fig. 3, $a, b$ ). The difficulty of studying it was that the smallest multicolored stripes were visible in the baulk only in the first half hour after scraping; as soon as the wall dried out, everything merged into a single mass.

In total, five baulks were cleared in the kurgan; R0 in the central part, R1 and R3 in the southern, and R2 and $\mathrm{R} 4$ in the northern part.

For laboratory study, samples were taken from the clay blocks located on the surface of the kurgan (1); in the kurgan, at a depth of about 1.0-1.5 m from the surface (2); and from the remains of the structure on the periphery of the kurgan (3). In the depths of the kurgan, samples were taken from various mud coatings. Two types of samples were taken from blocks and coatings: loose samples (for analytical study) and undisturbed micromonoliths (for micromorphological analysis). From the element with a striped pattern, samples were taken only for micromorphological study.

Under laboratory conditions, the grain size analysis of bulk samples, using sodium pyrophosphate for dispersion, was performed; the content of organic carbon was determined by the Tyurin's method as modified by Antonova et al. (Orlov, Grishina, 1981). The content of $\mathrm{CO}_{2}$ released during oxidation was determined on a chromatograph, and the $\mathrm{CO}_{2}$ of carbonates was determined manometrically by the pressure difference in the control and in the sample in sealed vessels with rubber plugs, in 


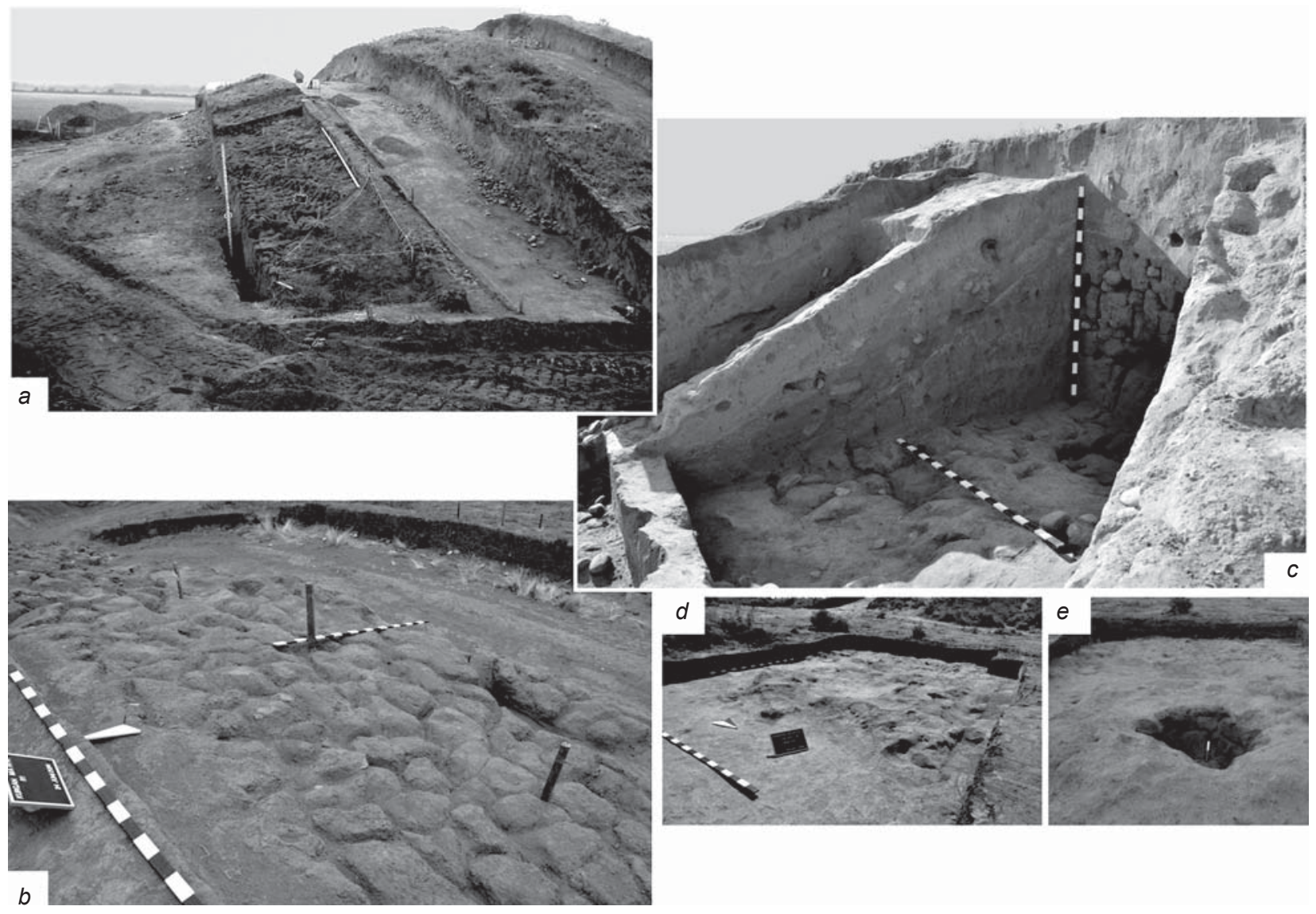

Fig. 1. Sun-dried mud "bricks" in the construction of the Marfa kurgan.

$a, b$ - on the surface of the kurgan (immediately below the sod); $c$ - at a depth of the kurgan, about 1.0-1.5 m from the surface; $d, e-$ from a heavily damaged building on the periphery of the kurgan, eastern side.
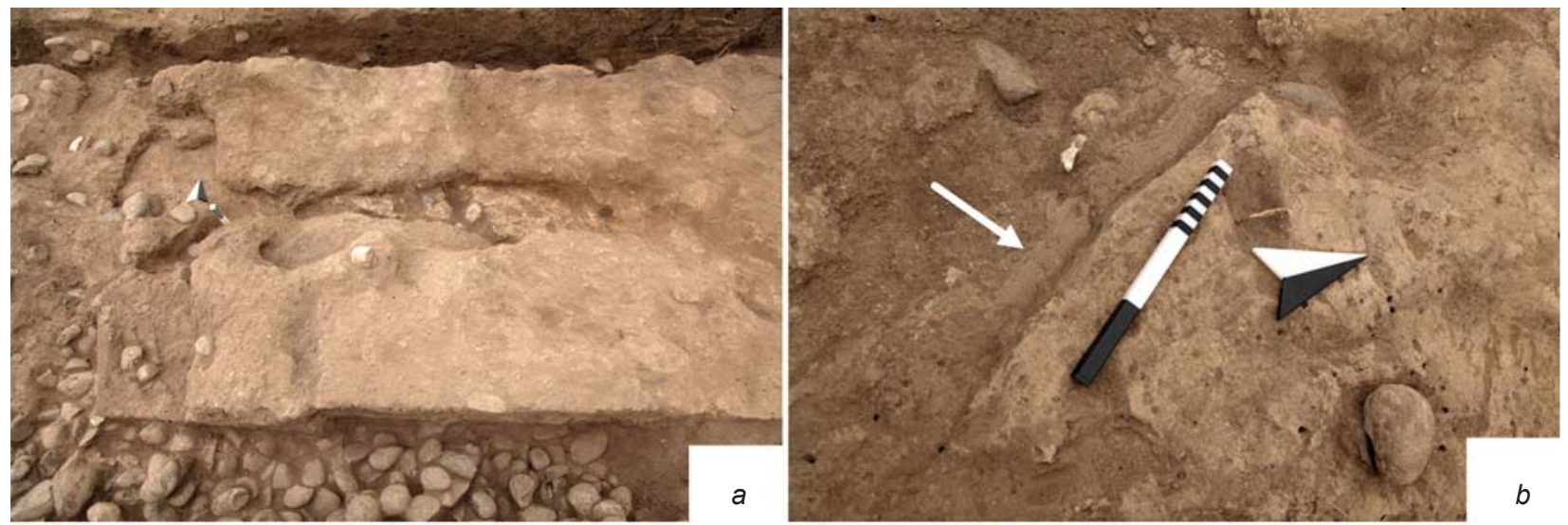

Fig. 2. Clay coatings in the construction of the Marfa kurgan.

$a$ - the "foundation" of a building made of mud blocks-"bricks" in the northern part of the kurgan; $b$ - coatings fastening the blocks of yellow (black and white arrow, location of the scale bar) and brown (white arrow) color.

which the samples reacted with $10 \%$ hydrochloric acid; the results were converted to C (Vorobyeva, 1998).

Sections were made from undisturbed samples. Micromorphological analysis of thin sections was carried out with an AxioScope A1 Carl Zeiss microscope at the Center for Collective Use of the Institute of Physicochemical and Biological Problems in Soil Science of the Russian Academy of Sciences. For comparison 


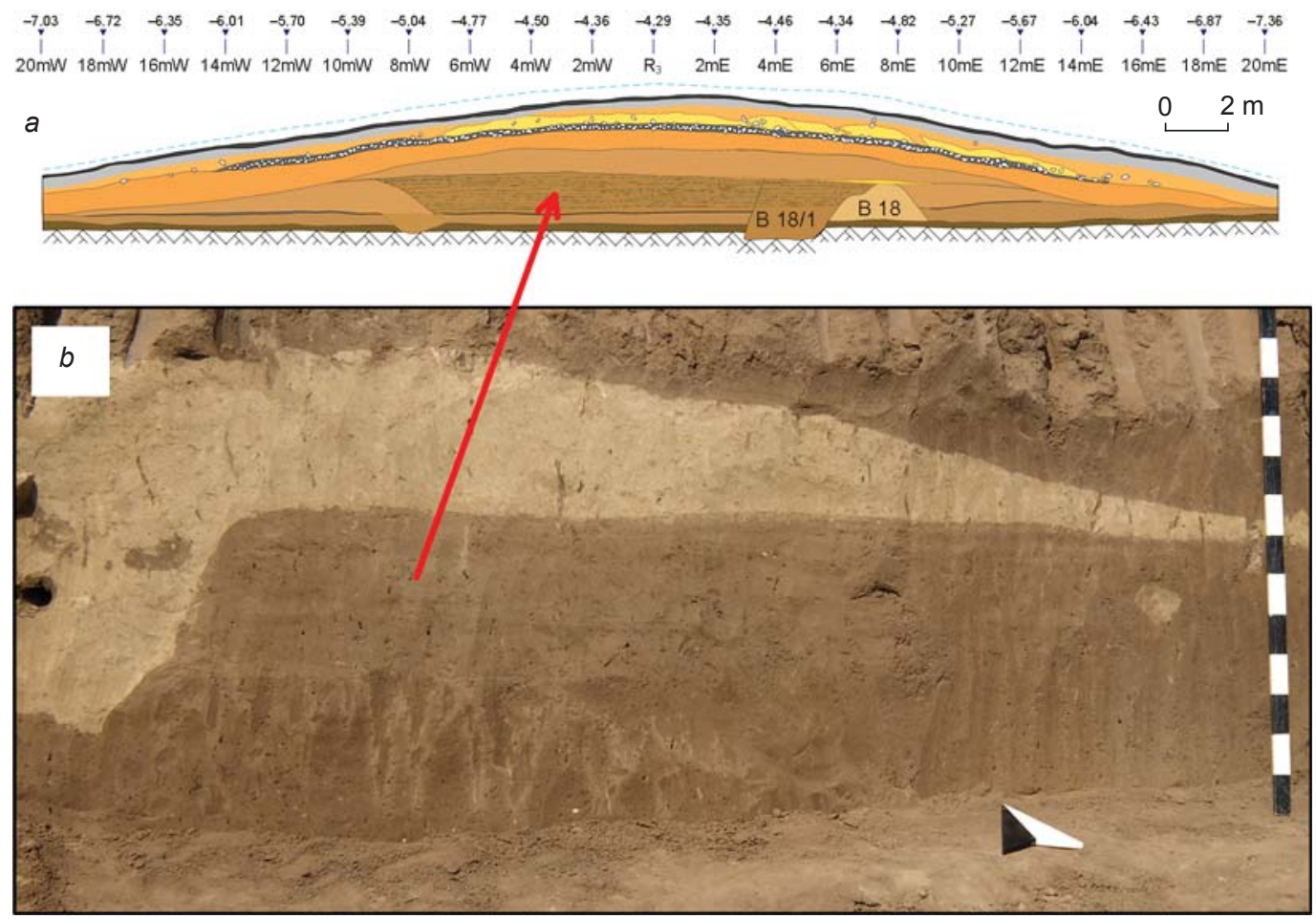

Fig. 3. The striped element on the scheme of baulk R3, southern face $(a)$, and in the photo $(b)$.

with samples from the construction of the Marfa kurgan, thin sections were made from samples taken in the deep horizons of soil sections under the kurgan (buried soils) and near it (background surface soils), and loess from the quarry $15 \mathrm{~km}$ north-north-west of the kurgan.

\section{Results \\ Research into the chemical and granulometric composition}

Preliminary studies (Khokhlova, Khokhlov, Nagler, 2017) have shown that in the surface layers of the kurgan, the construction material underwent robust processing during soil formation processes; therefore, in this work, only samples from the internal parts of the structure, as well as from blocks on the periphery of the kurgan, are studied to identify their chemical and granulometric composition and compared to samples from soils and loess.

For all of the analyzed characteristics, the blocks and coatings vary significantly, so analysis of the data obtained allowed us to make more or less reasonable assumptions.

The content of organic carbon $\left(\mathrm{C}_{\text {org }}\right)$ in the coatings is mostly high, $0.92-0.58 \%$, while in blocks it is most often within $0.41-0.34 \%$; but there are also very small values, $0.03-0.11 \%$, which are not recorded in the coatings. It can be concluded that in most cases the coatings contain more organic carbon than blocks, in which its content can be very small. In loess samples, the organic carbon content varied from 0.01 to $0.15 \%$. Some blocks in terms of this characteristic were close to the loess samples.

The carbon content of carbonates $\left(\mathrm{C}_{\text {carb }}\right)$ in the blocks is greater than in the coatings. If in the blocks the value of this index is no less than 1.07 , but not more than $1.64 \%$, then in the coatings the minimum is 0.52 , and the maximum is $1.53 \%$. According to the content of $\mathrm{C}_{\text {carb }}$, the samples of loess show values close to the blocks, in which the variation of this characteristic is in the range of $1.20-1.65 \%$.

Values for water $\mathrm{pH}$ and loss-on-ignition for blocks and coatings are higher than for loess. With a high degree of probability, coatings and blocks were made with the addition of some material.

Both blocks and coatings correspond to a rather uniform sample of the content of silt fraction $(<0.001 \mathrm{~mm})$ within $12-13 \%$. Single samples contain more (15-16\%) or less (9.2-9.6\%) silt. We can conclude that the blocks and the coatings show similarity in the content of the silt fraction. In this case, both blocks and coatings differ from the loess in the content of this very finely dispersed fraction. In the analyzed structural elements of the kurgan, the silt content is often higher than in natural loess. Only in the sample of loess from the quarry $15 \mathrm{~km}$ from the monument, the silt content is $18.5 \%$, which exceeds the content of this fraction in all samples from Marfa's construction. This fact suggests that the material for 
creating the kurgan was mined in the immediate vicinity of the construction site.

To continue the discussion in this direction, the contents of the average proportion of sand $(0.25-$ $1.0 \mathrm{~mm}$ ) are very important, which are the first to be determined when analyzing the particle size distribution by filtering the suspension through a sieve with $0.25 \mathrm{~mm}$ mesh. In the total sample, coatings show the lower contents of this proportion more often than blocks; but on the whole, the differences in this indicator between blocks and coatings are insignificant. At the same time, in the loess sample taken in the quarry, the content of this fraction is much lower than in all samples from Marfa's structural elements (2.5\% versus $15-24 \%)$. Concurrently, the content of the $0.25-1.0 \mathrm{~mm}$ fraction in loess samples from the deep layers of surface and buried soil is very close to that in the samples of blocks and coatings. This fact also argues in favor of a version about the location of the source of material for construction near the kurgan.

The content of physical clay $(<0.01 \mathrm{~mm})$ and physical sand $(>0.01 \mathrm{~mm})$ (both in the blocks and in the coatings) is close to the "ideal" recipe for a clay product in which the clay content does not exceed $30 \%$, and the sand is not less than $50 \%$ (in our case, $25-35$ and $65-75 \%$, respectively). This appears to be not accidental; the ancient builders probably knew the recipe for getting the "right" clay mixture.

\section{Micromorphological analysis}

Soil and loess. First, a micromorphological analysis of soils not affected by human activity is given - the background surface soil (section Mf1f-13) and the soil buried under the southern hollow of the kurgan (section Mf2p-13), as well as loess used as a reference for comparison.

In the layer at a depth of 50-55 cm of surface soil, the following signs were visible: (i) vigorous activity of soil biota - plant debris in voids, discharges of the mesofauna, and the crushing of soil material; (ii) humus accumulation process - round, brown-colored aggregates of various dimensions and order; (iii) mobility of humus-ferrous material-porostriated and granostriated b-fabric.

In the layer at a depth of 85-90 cm of surface soil, the most noticeable are the signs of carbonate accumulation and transformation of the initial (lithogenic, inherent to loess) carbonate substance under the influence of pedogenesis. Nodules, both cryptocrystalline, inherited from the original rock (loess), and recrystallized, composed of relatively large sparite crystals, were found in the groundmass. A significant microarea of the thin section prepared from samples of this layer was occupied by carbonate coatings in relatively large voids.
The micromass contained small elongated and rounded, occasionally recrystallized, fragments of carbonate shells.

In the buried soil at a depth of 50-55 cm, organic matter is represented by amorphous black or brownishblack spots scattered in the micromass and on top of the grains of minerals. The lithogenic carbonate nodules in the micromass were mainly recrystallized and were rarely found in their "initial" cryptocrystalline appearance; carbonate acuumulations were present in the form of coatings in the voids or created a granostriated b-fabic of the clay-carbonate composition.

In the layer at a depth of $85-90 \mathrm{~cm}$ of buried soil, there are numerous small cryptocrystalline and recrystallized carbonate nodules in micromass, and a lot of elongated fragments of carbonate shells. Thick carbonate coatings were located in the voids, and granostriated b-fabric of clay-carbonate composition was visible. There was a specific type of plagioclase grains; such grains were not found in horizons located closer to the surface in the studied soil profile.

Samples of loess material that was practically unaffected by pedogenesis, which were taken from deep horizons of surface soil and of soils buried beneath the kurgan, as well as from the loess quarry $15 \mathrm{~km}$ from the Marfa kurgan, demonstrate a high degree of carbonation. Basically, these are the so-called primary (or lithogenic) carbonates: fragments of shells of various sizes and shapes (Fig. 4, $a-c$, orange arrows), and many cryptocrystalline rounded nodules (Fig. 4, $a, b$, yellow arrows). Recrystallized nodules and sparite grains dispersed in the groundmass are rare in loess samples from soils near Marfa. At the same time, the loess sample from the quarry exhibits a high degree of saturation of the micromass with carbonates, and gypsum is also found in it (Fig. 4, $d$ ), which we could not find in deep soil horizons near the kurgan.

Blocks- "bricks". A micromorphological study of samples from the surface layers of the kurgan structure made it possible to record the nearly complete processing of the material by soil-forming processes: a lot of coprolites, zoogenic crushing and loosening of the soil mass, plant residues with preserved cell structure in the voids (Fig. 5, $a$, orange arrow), porostriated b-fabric of the humus-clay-ferrous composition (Fig. 5, $a$, yellow arrow). At the same time, inside this processed and loosened material, there occur microfragments of a darker, and most importantly, much more densely packed and saturated with fine-dispersed (clayey) substance of an "extraneous", "foreign" material (Fig. 5, a, green arrow; $b$ ). Their size is $5-6$ thousand microns $(5-6 \mathrm{~mm})$ and less. These microfragments are more common, and their sizes are larger in the layer at a depth of $25-30 \mathrm{~cm}$ than in the layer at a depth of 35-40 cm (Fig. 5, c, d). In the layer at a depth of 35-40 cm, these "foreign" microfragments are more difficult to distinguish from "ordinary" soil mass, since the degree of development by pedogenic processes 

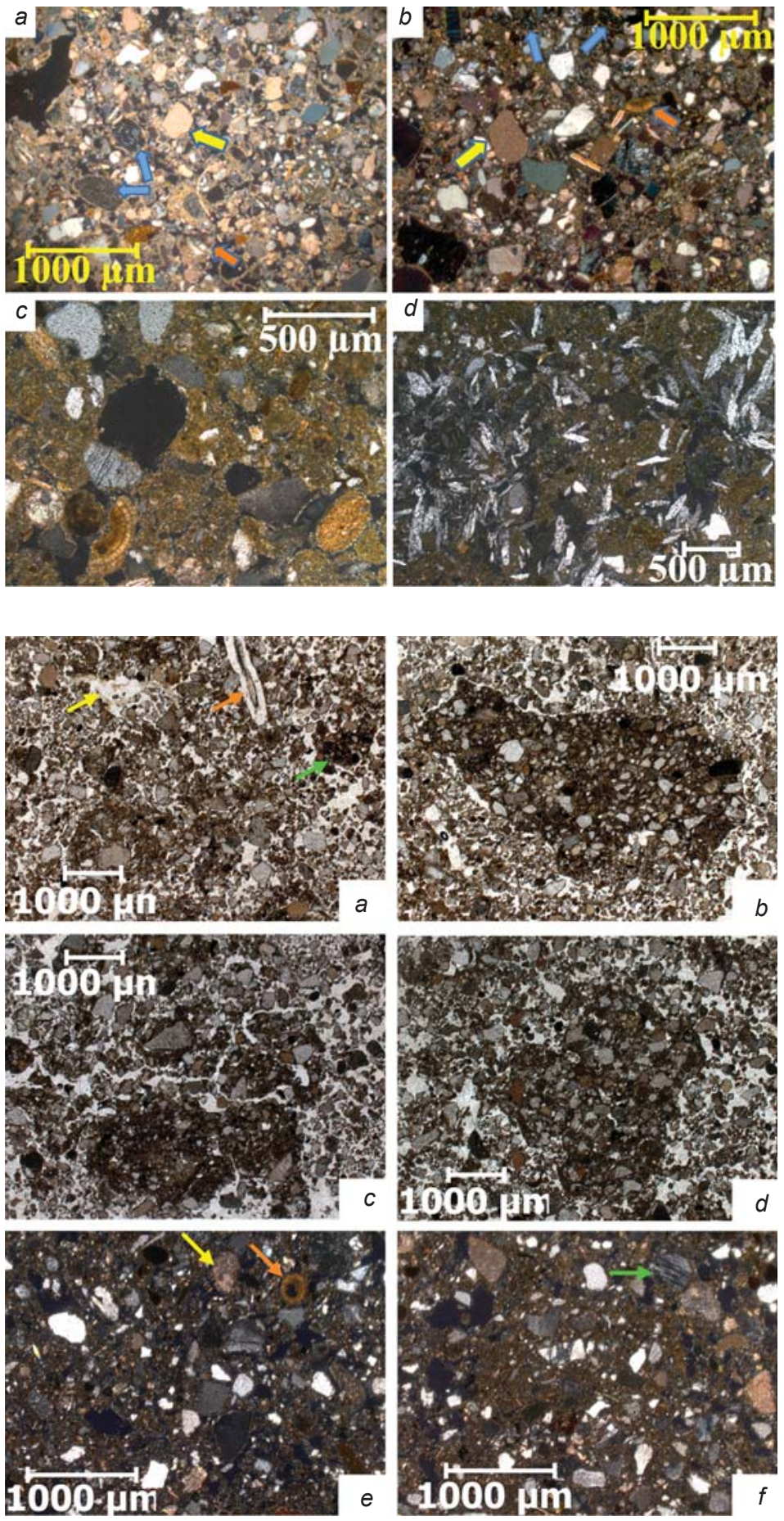

Fig. 4. Microstructure of loess from a layer at a depth of $160-170 \mathrm{~cm}$.

$a$ - section Mf1f-13; $b$ - section Mf2p-13; $c, d$ - quarry $15 \mathrm{~km}$ from the Marfa kurgan.

$a, b$-strongly carbonated material: rounded fragments of shells with a preserved pattern (orange arrows) and a lot of elongated fragments, a lot of cryptocrystalline nodules (yellow arrows), granostriated b-fabric of carbonate-clay composition, clearly visible grains of plagioclase (blue arrows); $c$ - rounded and elongated fragments of shells, carbonates impregnate micromass; $d$-in the carbonate impregnation, there are many leafy crystals of gypsum.

All photos were taken with an analyzer, XPL.

Fig. 5. Microstructure of samples from the kurgan construction, sampling depth $25-30$ and $35-40 \mathrm{~cm}$ from the kurgan surface.

$a$ - the "normal" structure of the humus horizon of soil in the mound: plant residue with preserved cell structure in the void (orange arrow), humus-clay-ferrous finely dispersed material in the void (yellow arrow), zoogenic crushing of the soil mass, rounded amorphous humic aggregates (green arrow), layer (sampling depth) $25-30 \mathrm{~cm}$; $b-$ an angular microfragment of a darker and densely packed material with sharp boundaries, layer (sampling depth) 25-30 cm; $c$ - destruction of a fragment of a densely packed dark material: broken by cracks, rounded in shape, diffuse border, layer (sampling depth) 25$30 \mathrm{~cm} ; d$-microfragment of a darker and densely packed material inside the biogenically mixed and loosened micromass, its boundary is sharp, layer (sampling depth) $35-40 \mathrm{~cm} ; e-$ shell fragments (orange arrow) and recrystallized carbonates in micromass (yellow arrow), layer (sampling depth) $35-40 \mathrm{~cm} ; f$ - plagioclase grain (green arrow), layer (sampling depth) 35-40 cm. Photos $a-d$ were taken without an analyzer, PPL, $e, f-$ with an analyzer, XPL. decreases as they move deeper into the kurgan structure, and the "foreign" fragments merge together to form a "body" of a block. Fragments of carbonate (aragonite) shells and recrystallized carbonate nodules, as well as plagioclase grains, are found inside microfragments (Fig. 5, $e, f$ ).

Thin-sections from blocks from a depth of more than $1 \mathrm{~m}$ from the surface of the kurgan were studied, as well as blocks found on the periphery of the kurgan (Fig. 6).
This allowed us to establish common features of the microstructure of the mud blocks of the Martha kurgan:

porphyric c/f related distribution-finely dispersed material completely fills the space between coarse particles; grains of the mineral skeleton show a predominantly medium sand size (Fig. 6);

around almost every mineral grain, a cavity (hollow) is observed, repeating the contour of this grain, which is typical of material dried after compaction in the wet state (Fig. 6, a); 

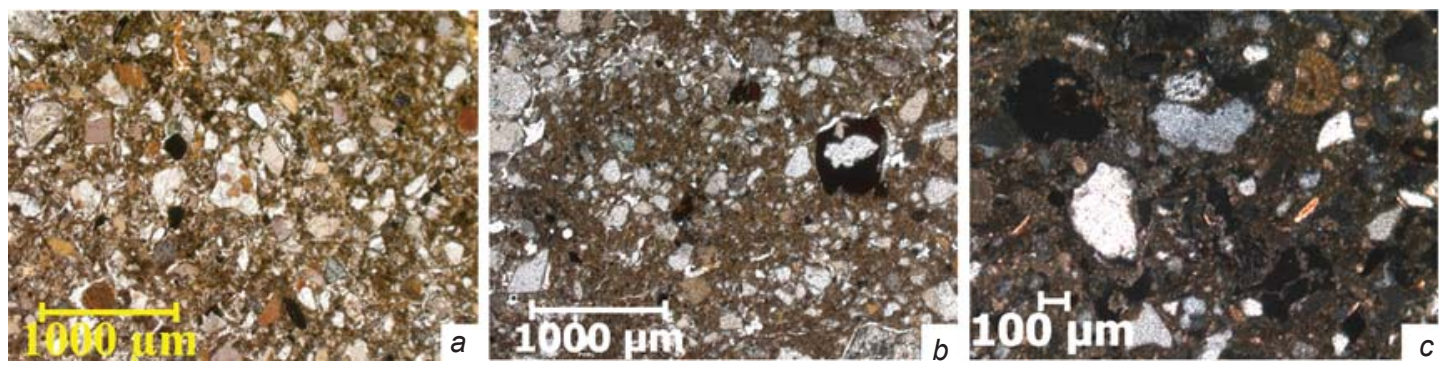

Fig. 6. Microstructure of mud blocks from the construction of the Marfa kurgan.

$a$-around the grains of the mineral skeleton, there are voids repeating the contour of each grain; in general, the micromass is highly compacted, small coatings of clay-ferrous composition are observed in small voids; $b$ - porphyric $\mathrm{c} / \mathrm{f}$ related distribution, crack network around large grains of the mineral skeleton, and in the upper part—drying cracks, black and brown spots in the voids, and micromass; $c-$ a fragment of a round carbonate shell, dispersed sparite grains and recrystallized carbonate accumulations in voids and in micromass, plagioclase grains are visible in the lower part. Photos $a, b$ were taken without an analyzer, PPL, $c$ - with an analyzer, XPL.

black or dark brown spots of organo-ferrous composition are scattered in the micromass, or appear in the voids (Fig. $6, b$ );

many carbonate accumulations, such as rounded or elongated shell fragments, recrystallized sparite grains, or cryptocrystalline nodules (Fig. 6, c); and

plagioclase grains (Fig. 6, $c$, lower part) clearly show that the material for the blocks was extracted from deep soil horizons, since there are no such grains in the surface horizons.

Based on the analysis of micromorphology and material composition, it was found that the material for the blocks-"bricks" was taken from the pits that revealed soil horizons at a depth of about $70-100 \mathrm{~cm}$ from the surface (i.e., from deposits lying below the soil layer stained with humus), in the immediate vicinity of the kurgan, and was mixed with river silt. The addition of river silt to this material is evidenced by the data of phytolith analysis (Khokhlova, Khokhlov, Nagler, 2017).
Coatings. A micromorphological analysis of composition of the coatings that fastened the "bricks" into a single masonry during the construction of the kurgan structure showed that the carbonate substance served as the predominant binder in these cementitious masses. According to micro observations, carbonates completely penetrate the micromass of such cement (Fig. 7,a), there are a very large number of carbonate shells $($ Fig. $7, c$ ) that retain their original appearance (Fig. 7, $c$, yellow arrows), with initial signs of dissolution (Fig. 7, $c$, the edge of a large fragment of the shell on the right side of the photo), as well as some that are swollen, recrystallized, and almost completely lost their original appearance (Fig. 7, $c$, white arrows). It is likely that upon soaking loess and river clay material, in which clay and carbonates were originally presented separately, under the influence of water and as a result of thorough mixing, a physicochemical transformation took place in it, and a single micromass of clay-carbonate composition was
Fig. 7. The microstructure of coatings. $a$ - carbonates completely impregnate the micromass; $b$ - micromass of clay-ferrous composition with a small addition of organic matter; $c$ - there are a lot of carbonate shells scattered in the micromass, which retain their original appearance (yellow arrows) and show initial signs of dissolution (the edge of a large fragment of the shell on the right side of the photo), many of them melted, recrystallized, and lost their original appearance (white arrows); $d$-loosening of the coating as a result of the activity of the mesofauna: the passages of small worms with crashed plant debris are visible, and darker compacted undisturbed microfragments are nearby. Photos $b, d$ were taken without an analyzer, PPL, $a, c-$ with an analyzer, XPL.
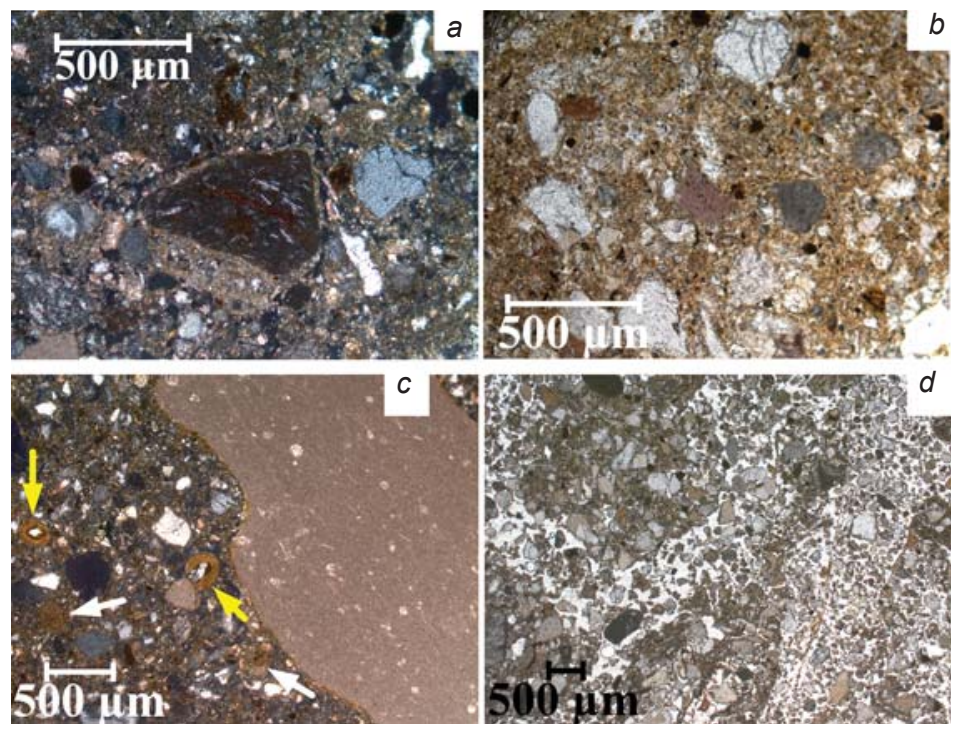
obtained. In the blocks-"bricks", the formation of a single fused clay-carbonate substance (carbonate impregnation) occurred on a much smaller scale.

Sometimes, the coatings had a brown or reddish hue (see Fig. 2, $b$, white arrow). During micro-observations, it was found that in the brown coating, the binder was iron; its oxides impregnated the micromass, which in this case had a clay-ferrous composition (Fig. 7, b). To obtain brown coatings-cements, clay was necessarily taken from the river, since the clay-ferrous composition of the fine soil is not at all characteristic of the chernozem surrounding the kurgan. This clay was also enriched with organic matter, but iron oxides were the main coloring component. Notably, clay-ferrous cements were used singly, for special cases, while the carbonate component absolutely prevailed in the coatings when bonding building blocks or stones in the structures of the Marfa kurgan. In general, the coatings, although they were distinguished by a much denser addition than even the clay mass from which the mud blocks-"bricks" were composed, were just as active as the blocks, which were destroyed under the influence of burrowing forms - worms, insects, larvae, etc. (Fig. 7, $d$ ).

Considering that in the material composition of the coatings, the content of organic carbon was most often higher than in the blocks, and carbon content of carbonates was lower, we can conclude that there were minor differences in the methods of preparing the material for blocks and coatings. More river silt was added to the clay coating solution; it was held for a much longer time in water, and subjected to more prolonged and more thorough mechanical action (mixing), due to which the
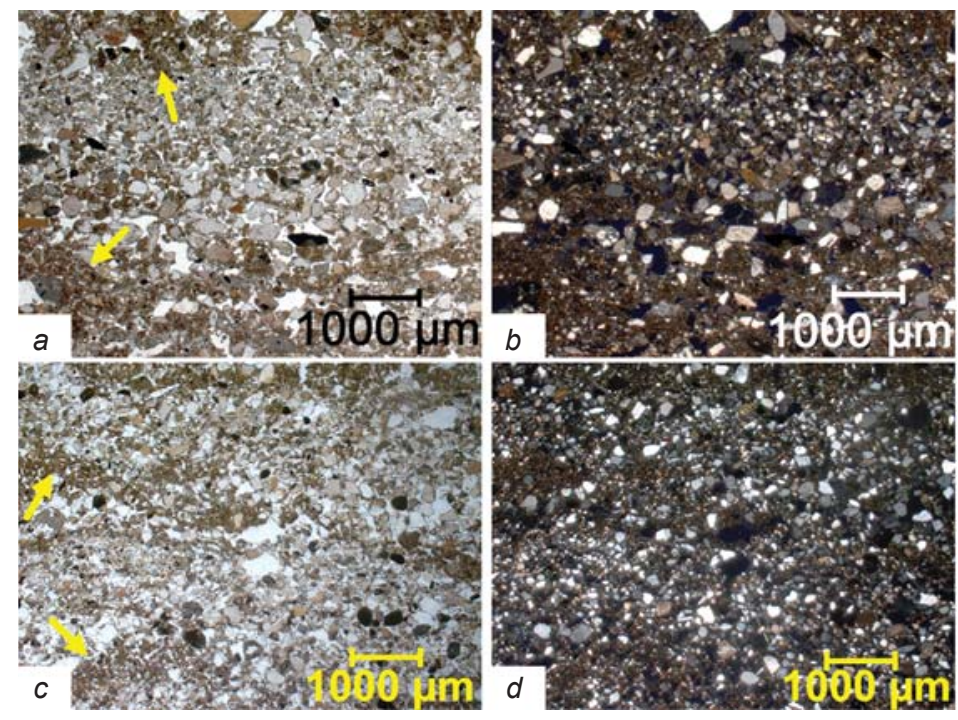

Fig. 8. The microstructure of the striped element in the construction of the Marfa kurgan.

$a, b$ - laminas of mineral grains of various sizes are clearly sustained; $c, d$-laminas are not sustained along the strike, intermittent. Yellow arrows indicate laminas of finely divided material. Photos $a, c$ were taken without an analyzer, PPL, $b, d-$ with an analyzer, XPL. initially heterogeneous clay and carbonate substance was converted into a single, finely divided mass of claycarbonate. It can be argued that the carbonate substance in this method of manufacturing the coatings became quite adhesive. If the composition of the coatings was clay-ferrous, then the material for them was most likely taken from river silt, since only in river sediments was silt carbon-free.

Striped structural element. A micromorphological analysis of material of the striped structural element found on the southern periphery of the kurgan made it possible to trace the sorting of coarse and finely dispersed mineral grains that made up laminas with a thickness of ca $1 \mathrm{~mm}$ (Fig. 8). Sometimes a lamina consisted of very finely dispersed particles of clayey or finely dusty dimensions (Fig. 8, $a, c$, yellow arrows). Microareas were observed in thin sections, where the laminas were sustained very clearly along the strike (Fig. 8, $a, b$ ), but more often they were unstable, intermittent, and sinuous (Fig. 8, $c, d$ ). When studying thin sections with an analyzer (Fig. 8, $b$, d), another important observation was made: the laminas were not interconnected by clay-carbonate or clay-ferrous finely dispersed material. Among the mineral grains, small fragments of shells or carbonate nodules occur, but they act as components of the mineral skeleton, and do not form a finely divided binder.

The striped structural element underlying the stone crepidoma probably refers to a layer formed during one of the early periods of Marfa's construction. Previously, researchers noted the striped structure of the clay material, which could be the result of sorting the material during the destruction of adobe structures (Friesem et al., 2011). Obviously, weather events such as precipitation, wind, etc. caused damage to the structure created from sun-dried mud "bricks"; it gradually collapsed, and sedimentation (sorting) of variously-sized mineral fractions under the influence of gravity occurred. The fact that this was a process that occurred from time to time and under the influence of various forces (either light rain, heavy rain, strong wind or light) is suggested by the discontinuity, intermittence, tortuosity of small layers inside this structural element.

\section{Conclusions}

Structural materials and technical-technological approaches used in the construction of the Marfa kurgan were studied using methods of soil science and micromorphology. The kurgan began to be built by bearers of the Maykop culture in the Early Bronze Age (second half of the 4th millennium BC); 
construction continued in the Middle Bronze Age (3rd to 2nd millennium $\mathrm{BC}$ ) and in the Early Iron Age (1st millennium BC). The study of the remnants of sundried mud "bricks" from the surface of the kurgan, wellpreserved blocks that were inside the structure and on the periphery of the object, made it possible to establish their common origin (use of common raw materials). That is, the blocks were molded by thoroughly mixing and compacting the material from the loess, taken from the relatively deep pits adjacent to the kurgan, with the addition of river silt, without using plant materials.

The coatings had a much denser addition than the blocks, but the contents of the silty and finely dusty granulometric fractions of the coatings and the blocks did not differ. The binder component in the coatings was predominantly carbonate, much less often a ferrous substance, converted by mechanical action in the presence of water into a clay-carbonate-(ferrous) mass. The high density of the coatings is the result of the fact that clay material for them was kept in water much longer than for blocks; the disparate and coarse carbonate material that we observe in loess and soil horizons was transformed into a coherent finely divided clay-carbonate material.

On the periphery of the kurgan, a striped structural element was recorded, formed owing to the natural sedimentation of variously-sized mineral fractions under the influence of gravity in periods of showers and winds, during the destruction of the initial adobe structure. The next generation of builders used this element as the basis for stone crepidoma.

\section{Acknowledgements}

Field studies were supported by the Eurasian Department of the German Archaeological Institute. Micromorphological analysis was supported by the Russian Science Foundation (Project No. 19-18-00327). The article was prepared under the Public Contract (Topic No. 0191-2019-0046).

\section{References}

Aleksandrovsky A.L., Khokhlova O.S., Sedov S.N. 2004 Bolshoy Ipatovskiy kurgan glazami pochvoveda. Rossiyskaya arkheologiya, No. 2: 61-70.

\section{Bazhenov A.I., Safarova L.R., Yakimov A.S.,}

Tairov A.D. 2013

"Kirpich-tsement" - universalnaya sistema dlya stroitelstva kurganov. In Etnicheskiye vzaimodeistviya na Yuzhnom Urale. Chelyabinsk: Rifei, pp. 251-257.

Borisov A.V., Krivosheev M.V., Mimokhod R.A., El'tsov M.V. 2019

"Sod blocks" in kurgan mounds: Historical and soil features of the technique of tumuli erection. Journal of Archaeological Science, rep. 24: 122-131.
Bronnikova M.A., Panin A.V., Murasheva V.V., Golyeva A.A. 2016

Soil micromorphology in archaeology: History, objectives, possibilities and prospects. Byulleten Pochvennogo instituta im. V.V. Dokuchaeva, vol. 86: 35-45. URL: https://doi. org/10.19047/0136-1694-2016-86-35-45.

\section{Cammas C. 2018}

Micromorphology of earth building materials: Toward the reconstruction of former technological processes (Protohistoric and Historic Periods). Quaternary International, vol. 483: 160-179.

\section{Chernykh L.A., Daragan M.N. 2014}

Kurgany epokhi eneolita - bronzy mezhdurechya Bazavluk Solenaya - Chertomlyk. Kiev: Oleg Filyuk.

\section{Courty M.-A., Goldberg P., Macphail R.-I. 1989}

Soils and Micromorphology in Archaeology. Cambridge: Cambridge Univ. Press.

Efremova T.F. (s.a.)

Noviy slovar russkogo yazyka. Tolkovoobrazovatelniy. Slova na bukvu K. URL: https://classes.ru/all-russian/russiandictionary-Efremova.htm?letter=11 (Accessed April 11, 2020).

Emery V.L. 2011

Mud-brick. In UCLA Encyclopedia of Egyptology, W. Wendrich (ed.). Los Angeles: Univ. of California, pp. 1-10.

Friesem D., Boaretto E., Eliyahu-Behar A.,

Shahack-Gross R. 2011

Degradation of mud brick houses in an arid environment: A geoarchaeological model. Journal of Archaeological Science, vol. 38 (5): 1135-1147.

\section{Friesem D.E., Karkanas P., Tsartsidou G.,}

Shahack-Gross R. 2014

Sedimentary processes involved in mud brick degradation in temperate environments: A micromorphological approach in an ethnoarchaeological context in northern Greece. Journal of Archaeological Science, vol. 41: 556-567.

Friesem D.E., Wattez J., Onfray M. 2017

Earth construction materials. In Archaeological Soil and Sediment Micromorphology, C. Nicosia, G.R. Stoops (eds.). New York: Wiley, pp. 99-110.

\section{Goldberg P. 1979}

Geology of Late Bronze age mudbrick from Tel Lachish. Tel Aviv, vol. 6 (1/2): 60-67.

Golyeva A.A., Khokhlova O.S. 2010

Rekonstruktsiya etapov sozdaniya Bolshogo Sintashtinskogo kurgana (Chelyabinskaya oblast) na osnove paleogeograficheskikh dannykh. Izvestiya RAN. Ser. geogr., No. 6: 67-76.

\section{Gryaznov M.P. 1961}

Kurgan kak arkhitekturniy pamyatnik. In Tezisy dokl. na zasedaniyakh, posvyashch. itogam polev. issled. v $1960 \mathrm{~g}$. Moscow: pp. 22-25.

Hohn C.M. 2003

ABCs of making adobe bricks. URL: https://aces.nmsu.edu/ pubs/_g/G521/.

\section{Kemp B. 2000}

Soil (including mud-brick architecture). In Ancient Egyptian Materials and Technology, P. Nicholson, I. Shaw (eds.). Cambridge: Cambridge Univ. Press, pp. 78-103.

Khokhlova O.S., Khokhlov A.A., Nagler A.O. 2017

Izucheniye konstruktsii kurgannykh sooruzheniy metodami pochvovedeniya (na primere kurgana Marfa v Stavropolskom 
kraye). In Multidistsiplinarniye metody v arkheologii. Noveishiye itogi i perspektivy. Novosibirsk: IAET SO RAN, pp. 358-367.

Khokhlova O., Nagler A. 2018

Micromorphological analysis in studying the features of mud-brick construction of the Marfa kurgan in the Stavropol region, Russia. In International Workshop on Archaeological Soil Micromorphology. 1-3 August 2018. Brussels: p. 9.

\section{Kramer S.N. 2010}

The Sumerians: Their History, Culture, and Character. Chicago: Univ. of Chicago Press.

\section{Love S. 2017}

Field methods for the analysis of mud brick architecture. Journal of Field Archaeology, vol. 42 (4): 351-363.

Mozolevsky B.N., Polin S.V. 2005

Kurgany skifskogo Gerrosa IV v. do n.e. Kiev: Stilos.

Nagler A. 2013a

Grabanlagen der frühen Nomaden in der eurasischen Steppe im 1 Jahrtausend v. Chr. In Unbekanntes Kazachstan Archäologie im Herzen Asiens, Bd. 2. Bochum: Deutsches Bergbau-Museum, pp. 609-620.

Nagler A.O. 2013b

Pogrebalniye sooruzheniya rannego zheleznogo veka stepei Yevrazii. Nauchnoye obozreniye Sayano-Altaya, No. 1 (5): 222-232.

Nagler A.O. 2015

Kurgany Bolshoy stepi kak arkhitekturniye sooruzheniya. Nauka iz pervykh ruk, vol. 64 (4): 70-85.

Nagler A. 2017

Kurgany Yevrazii - noviy vzglyad na pamyatniki i noviye zadachi ikh issledovaniya. In Multidistsiplinarniye metody $v$ arkheologii. Noveishiye itogi i perspektivy. Novosibirsk: Izd. IAET SO RAN, pp. 192-215.

Orlov D.S., Grishina L.A. 1981

Praktikum po khimii gumusa. Moscow: Izd. Mosk. Gos. Univ.

Parzinger G., Zaibert V.F., Nagler A.,

Pleshakov A.A. 2003

Bolshoy kurgan Baikara. Issledovaniye skifskogo svyatilishcha. Mainz: Philipp von Zabern.

Plekhanova L.N., Demkin V.A., Manakhov D.V. 2005

Paleopochvenniye issledovaniya kurganov epoch bronzy $\mathrm{i}$ rannego zheleza (II tys. do n.e.-I tys. n.e.) v stepnom Zauralye. Vestnik Moskovskogo universiteta. Ser. 17: Pochvovedeniye, No. 4: 3-10.

\section{Rolle R., Mursin V.Ju., Alekseev A.Ju. 1998}

Königskurgan Čertomlyk. Ein skythischer Grabhügel des 4. vorchristlichen Jahrhunderts, Bd. I. Mainz: Philipp von Zabern.

Rosen A.M. 1986

Cities of Clay: The Geoarcheology of Tells. Chicago: Univ. of Chicago Press.

\section{Vorobyeva L.A. 1998}

Khimicheskiy analiz pochv. Moscow: Izd. Mosk. Gos. Univ. Zdanovich G.B., Ivanov I.V., Khabdulina M.K. 1984

Opyt ispolzovaniya $\mathrm{v}$ arkheologii yestestvennykh metodov issledovaniya (kurgany Kara-oba i Obaly v Severnom Kazakhstane). Sovetskaya arkheologiya, No. 4: 35-48. 